\title{
TEL AVIV, ISRAEL - A WORLD CITY IN EVOLUTION: URBAN DEVELOPMENT AT A DEADEND OF THE GLOBAL ECONOMY
}

\author{
Baruch A. Kipnis \\ The University of Haifa, Mt. Carmel, Haifa, 31905, Israel \\ e-mail: baruch@univ.haifa.ac.il
}

\begin{abstract}
Tel Aviv was mentioned as a world city for the first time by Kellerman (1993) who emphasized the existence of leading economic functions typical for the late $20^{\text {th }}$ century city. This paper extends the notion of Tel Aviv as a world city in evolution, using up-to-date world city literature and indicators. Greater (metropolitan) Tel Aviv with 2.6 million population in 2000 (Tel Aviv City had 350000) has been Israel's primate urban agglomeration since the 1920s. Since the 1990s it has evolved into a hard core of Israel's post-industrial, globally orientated economy, and has displayed a post-modern physical ambience and social and cultural lifestyle. Tel Aviv evolved into a global city in spite of the fact that it is located at a frontier in its own region, the Mideast, and at the cul-de-sac site relative to the mainstream global economic centers with which it maintains most of its network links. In addition to common attributes of a world city one of the main assets of Tel Aviv is its high R\&D intensive industry, acting as a growth pole for the local and national economies. Future research avenues are an in-depth analysis of Tel Aviv`s social inequalities and the linkage patterns that Tel Aviv maintains with other urban centers of world city caliber.
\end{abstract}

Key words: world city, globalisation, Tel Aviv, Israel

\section{INTRODUCTION}

The notion of Tel Aviv as a world city introduced by Kellerman in 1993, emphasizing the existence of "leading economic functions typical of the late 20th century: hi-tech industries and a modern service economy". He credited Knight and Gappert (1984) as the first to name Tel Aviv among the cities which, according to Forbes of July 1983, "are the respective homes of two or more corporations that achieved substantial annual sales...". While Kellerman refers to Tel Aviv as a world city in broad terms, this paper extends the notion of Tel Aviv as a world city in evolution, using more recently established indicators to name a 
city as having a world city status. Beaverstock, et al. (1999) includes Tel Aviv with 23 other cities that mentioned at least once as world cities by 15 references of world city literature. In their own research, Beaverstock, et al. (1999) mentions Tel Aviv as having two out of four 'global' producer services (accountancy and advertising). As such it is placed among cities like Athens, Dublin, Helsinki, New Delhi, Philadelphia, Rio De Janeiro, and Vienna, that strongly evincing 'world-ness'.

This paper draws on the author's observations of the dynamics of change in greater Tel Aviv ${ }^{1}$ since the first half of the 1990s when it became the hard core of Israel's postindustrial globally oriented economy revealing post-modern physical ambience and social and cultural lifestyle.

The issues discussed in this paper are:

1. How has Tel Aviv City emerged as a dominating entity of the Israeli economy, society, and culture? ${ }^{2}$

2. When did Tel Aviv begin to play part of a center with the global reach of the 'quinary' sector of decision-making and control, and of the 'quaternary' sector of finance and advanced producer services?

3. Is Tel Aviv City's physical form advancing to resemble an urban center of a global caliber? And finally,

4. Why cannot Tel Aviv be an integral part of the process of 'going global' within its region, the 'Mideast, but instead affiliates itself, at a frontier 'cul-de-sac' position, with the leading global 'mega markets'?

5. At the opening, the world city concept and its major definition paradigms presented.

\section{ATTRIBUTES OF A 'WORLD CITY'}

What is 'world city-ness' and what are the elements of a world city? In late 1990s, world city literature challenged old established attributes that described a city that had qualified for a world city status. Leading the process were Beaverstock et al. (1999; 2000). They argued that a definition of 'city world-ness' should replace the existing paradigm of 'attributes without relations' by one that views a world city as an element of 'world cities in a network society'. Beaverstock et al., (2000) blamed the old paradigm for emphasizing the individual city, alone or in comparison with other cities. It depicted a world city as having one or a combination of attributes ${ }^{4}$ emphasizing its cosmopolitan lifestyle and its role as a center of a corporate and producers' service economy. As such, a world city is a center of command and control, which, which along with other centers, had initiated the creation of the 'international division of labor'. It acted as a major financial core ${ }^{5}$ and had a diversified

\footnotetext{
${ }^{1}$ Greater Tel Aviv denotes metropolitan Tel Aviv, inhabiting 2.6 million population (2000). Tel Aviv-Yaffo (Jaffa) City, the central city, has only 350,000 .

2 Tel Aviv City is described as a "city without an intermission", known in other places, as a "24-hour city" (Singapore) and the "city around the clock" (New York).

3 The 'mega markets' are North America, West Europe and the West Pacific Rim Dicken (1998).

${ }^{4}$ For references refer to Beaverstock, et al. $(1999 ; 2000)$.

${ }^{5}$ References are Reed (1981), Friedmann (1986; 1995), Thrift (1987) and Sassen (1991).
} 
agglomeration of advanced producer services. London, Tokyo, and New York headed a world city hierarchy defined by these attribute. In a few instances, a world city could be a 'privileged site' for reflexivity rooted in its specialized industry, producer services, knowledge, and learning structures (Strorper, 1997; Scott, 2000). ${ }^{6}$

The 'network paradigm' designed by Beaverstock and his colleagues $(1999 ; 2000)$ based on global office location strategies of four leading producing services: accountancy, advertising, banking/finance, and commercial law. Based on a worldwide sample of 143 major office centers of 74 companies in 263 cities they listed 55 world cities ranked into three groups by the number and importance of their leading producing services. Prime or Alpha (10 cities), Major or Beta (10 cities), and Minor or Gamma (35 cities). Tel Aviv belongs to the Gamma group only in two services, accountancy, and advertising (Beaverstock, et al., 1999). Therefore, it placed at the fourth group of cities - cities that showed relatively strong evidence of [future] world city formation.

Stanley's (2001) alternative regional model for $\mathrm{MENA}^{7}$ broadened the scope of the world city network paradigm in three elements: the most significant is his 'going global' regional model that helps to explain why Tel Aviv is a world city at the frontier of its own region, and a cul-de-sac in the global economy. Stanley argued that a region like MENA should not be organized at the nation state level, but ought to be embedded and linked into broader networks of exchange and flows like city hinterlands, city dyads, ${ }^{8}$ and city systems. He also extend world city-ness attributes to include, in addition to command and services, other sectors like creative service industries'. ${ }^{9}$ The mechanism through which a city attains world city-ness, according to Stanley, is the vital role of an agency. Cities and systems of cities develop, enhanced, empowered, or modified through the initiatives of their agencies, the 'actors' operating within the local power networks. The 'agency' model differs from Friedmann (1986, 1995; and Sassen's (1991) deterministic 'new world order'. The agency model is a grassroots one, in which agency actors develop a range of policies and actions aimed at advancing the status of their city within its own network (Stanley, 2001).

Sassen (2001) supports Stanley's model and in so doing adds an extra explanation for Tel Aviv's frontier - cul-de-sac location. She implies that the role played by a nation states in cross border flows has changed significantly because of privatization, deregulation and increased participation of national economic actors in global markets, and the entry of foreign firms into the national economic milieu. Because of improved connectivity, firms and their overseas outlets are now more firmly engaged in cross-border transactions in the form of investments, alliances among financial markets, and international labor markets for specialized service workers and professionals. Global cities, or those with global functions, have become the anchoring network of places - or 'global circuits' with multiple crossborder activities. Through these 'global circuits', one can better perceive globalization with the purpose of identifying the complex organizational frameworks that are both partly de

\footnotetext{
${ }^{6}$ Storper and Scott cited Hollywood as an example.

${ }^{7}$ MENA = Middle East and North Africa.

${ }^{8}$ Examples are Beirut-Damascus, Rabat-Casablanca, Cairo-Alexandria (Stanley, 2001).

${ }^{9}$ Creative services are architectural, interior and landscape design, fashion industry, publishing, software, music and cinema, etc'. A few have already become multinationals (Stanley, 2001).
} 
territorialized and partly spatially concentrated in cities (Sassen, 2001). Of note, is that Tel Aviv does not enjoy multiple cross-border activities with its neighbors.

A world city besides having large population size and allied functionally and spatially through loose cross-border links or through global linkages, should exhibit other attributes named by the paradigm of 'attributes without relations'. They are: cosmopolitan ambience and a liberal life style, a site of top multinational command centers, advanced producers' services, major financial institutions, and an array of 'creative service industries'. A city with world status needs an up-to-date infrastructure like international airport, information and communications systems, a web of social, cultural, community services and facilities, and a range of trendy consumer services (Goldberg and Davis, 1988). Equally important, is that its public, particularly its agency actors, must initiate consistent strategies and policies aimed at new innovative opportunities (Goldberg and Davis, 1988). Finally, they should work hard to reduce social disparities (Stedman and Turner, 1996), and, adopt a policy of 'thinking globally, acting locally' (Gappert, 1989).

\section{TEL AVIV: ISRAEL'S HARD CORE REGION}

Tel Aviv has gained its world city (in evolution) status in association with Israel entry into the 'post-industrial' age and its affiliation with the global economy. Many valuable resources discuss the concepts of a postindustrial era and of global economy, and reveal how Israel linked into this an entity. They are summarized in many of my previous writings (for example, Kipnis, 1998b; 2001; Kipnis and Bornstein 2001). The point of departure of this paper is that Greater Tel Aviv has already crossed the threshold of going global, and it has earned world city standing in spite of its frontier location in its region, the Middle East, and its situation at a dead-end site relative to the global economy.

Tel Aviv built as a Jewish suburban garden city north of Arab Jaffa in 1909. Two decades later it surpassed Jaffa in population and economic activity to become, together with Jaffa, the 'primate city' of the Land of Israel. In 1948 when the Arabs of Jaffa took refuge, Jaffa was united with Tel Aviv. Tel Aviv-Yaffo (Jaffa) became the central city of Greater Tel Aviv, but many of the images of a world city nested in Jaffa that emerged as a city with an international image during the second half of the $19^{\text {th }}$. The Ottomans who then ruled the area sought to boost Jaffa's control over the southern coastal plain of the Land of Israel, to allow safe operation of Jaffa port and to promote the city's economy (Ram, 1982; Kark, 1984; Kellerman 1993). The Ottomans laid a telegraph line to Europe and to Jerusalem (1865), opened a road to Jerusalem (1869), and formed a municipality of Jaffa (1871).

Jaffa became a cosmopolitan center, and American, German, and many other immigrants settled in it for religious and ideological reasons, supporting the Ottoman efforts to induce the city's economic base and its entrepreneurial environment. Jaffa rapidly grew into a secular, pluralistic, cosmopolitan society and an innovation oriented urban center. Jaffa's diversified ethnic groups, economy, and eclectic architecture also became the home base of many cultural activities such as theater, music, newspapers, and publishing houses (Kark, 1976; Kellerman, 1993). After WWI that marked the end of the Ottoman regime, Tel Aviv 
assumed the role of the main center of the region, and of the Jewish community at large. This process propelled by the fact that until the mid-1930s, Jaffa was the main entry port for Jewish immigrants; many who arrived had a sound educational background. Many had their arrived with their material wealth, which, together with their educational capabilities, helped Tel Aviv evolve into the hard core of the Jewish national territory of Israel (Kellerman, 1993). After 1948, and in spite of the Israeli government's vigorous population dispersal policy, the Tel Aviv region maintains its role as a primate core area of Israel (Lipshitz, 1996).

Figure 1: Greater Tel-Aviv in the national context in the year 2020

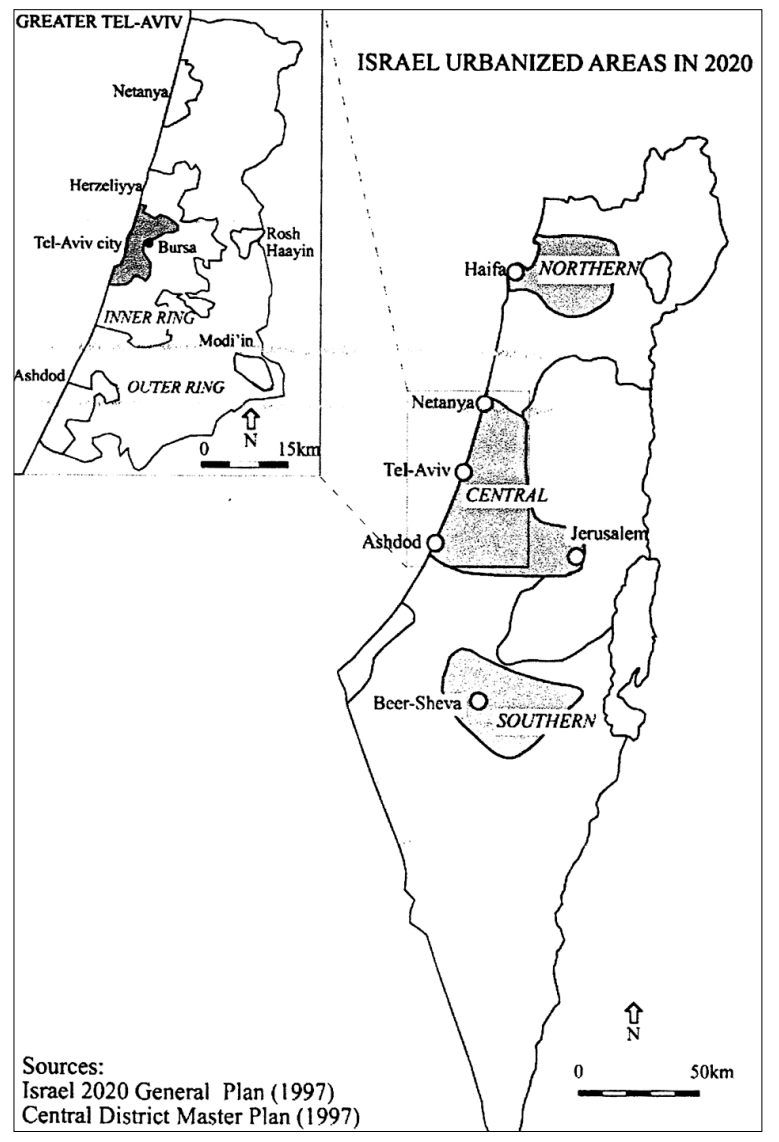

\section{TEL AVIV A SERVICE AND COMMAND CENTER}

For years the service industry was an important and dynamic activity of Tel Aviv City (Kellerman, 1986; 1993), but only in early 1960s it started to expand to occupy $1.7 \mathrm{~m}^{2}$ of floor space in mid 1990s. Most of the more recent increase took place in modern office 
towers that changed Tel Aviv's skyline completely. The Yizraeli Center, on the Ayalon freeway, Tel Aviv's major limited exit highway, is an example of a prestigious 'postmodern'-'post-industrial' office tower structure. At the end of the 1990s, two service industries led the employment profile -- finance, insurance, and business services, with $12.3 \%$ of the total employment (only $7.3 \%$ of total Israel), and public, community, and personal services, with $8.6 \%$. Tel Aviv is the financial capital of Israel, with all major banks having their headquarters in Tel Aviv's historical CBD.

The projected office space for 2020 was 3.3 million $\mathrm{m}^{2}$ (Pasternak, 1993), all in 'postmodern' type A office towers. Nearly all of the projected growth of office space, accommodates the fast growing producer services industries as well as command headquarters of Israeli and foreign firms. It has taken place along the eastern nucleus of the metropolitan CBD, most of it within the municipal boundaries of Tel Aviv City (Kipnis, 1998). Two of the northward expansions of the $\mathrm{CBD}$, both along the Ayalon freeway are the Bursa (the diamond exchange) in the city of Ramat Gan and Herzeliyya industrial park (Kipnis and Noam, 1998; Kipnis and Borenstein, 2001). The Ayalon section of the metropolitan CBD enjoys excellent accessibility to the rest of Greater Tel Aviv, the rest of Israel, and the rest of the global economy via Ben-Gurion Airport, located 15-20 minutes drive from Tel Aviv.

Greater Tel Aviv and its core region also evolved as a center of Israel's industry quinary sector of command and control, with $55.2 \%$ of the headquarters of Israel's mid1990s manufacturing firms were located in metropolitan Tel Aviv, primarily the large ones in terms of their number of employees. As expected, the more important concentration was outside Tel Aviv City. However, a central role played by the CBD of Tel Aviv City, and of the two adjuncts suburban office clusters, Herzeliyya and the Bursa, both a favored location of command headquarters of MNC and MLC. Greater Tel Aviv has attracted a large portion of domestic and foreign investments, to become an anchor of the Israel's post-industrial economy, accompanied by large-scale real-estates development, much in the form of hitech parks, inhabiting start-up intensive activity (Perman, 2000; Kipnis, 2001), making Greater Tel Aviv 'the startup metropolis' and hi-tech, information and telecommunication center (Kellerman, 1999). At the end of the 1990s, Greater Tel Aviv contained 86\% of Israel's hi-tech firms, hosting three of its main industries: communication, information technology, and the Internet. Last, but not the least, Tel Aviv, a secular, cosmopolitan city, is the main center of 'creative industry' including music, theater, dancing, visual arts, innovative medicine, and other scientific areas, to name but a few. Many of these have been actively involved in the global arena and have gained world fame, but always refer to Tel Aviv as their home base (Kummer, 2000).

All the above developments have had a forceful impact on Tel Aviv's physical layout, particularly its skyline. Until the 1960s, Tel Aviv City had made every effort to maintain its moderate building environment, strongly influenced by the Bauhaus style, ${ }^{10}$ with buildings not permitted to rise higher than three to four stories. The first tall building, 36 stories high, was the Shalom Tower, built in 1965 at the hub of Tel Aviv's historical CBD. In 1999 some 58 tall buildings, having 20 stories or more, and occupied by offices and by high-

${ }^{10} \mathrm{Tel}$ Avive with the largest concentration of Bauhaus buildings from early 1930s, is known as the 'white city'. 
level residences, were surveyed. Seventeen other tall buildings, including four 34-story high residential towers (located in the eastern neighborhood of Ramat Itzhak) were under construction. The highest building (50 stories high) is the Yizraeli Center built on the Ayalon in late 1990s. The peak period of tower building construction was during the 1990s, when 18 new tower buildings were built and 17 others were started. Many of the tall structures of the 1990s were 30 stories and more. The restructuring of Tel Aviv's skyline has been so impressive that a few web sites have mad a note out of it. Geocities (2001), for example, compared Tel Aviv to London, indicating that Tel Aviv's activity encourages high-rise buildings as space is at premium in Israel.

\section{WORLD CITY AT A DEAD-END OF THE GLOBAL ECONOMY}

Which are the global networks to which Tel Aviv is and /or will affiliate? Our thesis is that notwithstanding future geopolitical affairs in the Middle East, Tel Aviv as a world city will not be part of its own region or rather, one embedded into the broader Middle East network of exchange Stanley (2001), nor will it be within a circuit of [regional] world cities revealing cross-border inter-state dealings described by Sassen (2001). This situation will prevail at least in the near future, even if peace prevails. This does not exclude the option that Tel Aviv along with other Israeli and Middle East cities evolve into a peacetime east Mediterranean megalopolis (Kipnis, 1997). To sum up, at least for the time being, Tel Aviv situated at a frontier within its own region, or at a spatial 'dead end' in the global economy.

Tel Aviv and Israel at large is a periphery of the global core regions in terms of location, scale of its economy, markets, and access capital. Regardless of peace efforts, Israel is still a frontier relative to its bordering neighbors, some are belligerent and two maintain a 'cold' peace state of affairs and are reluctant fully to realize its inherent potential. As a 'culde-sac' Tel Aviv reveals a unique case of a city 'going global', one that is utterly affiliated only with the mainstream of the world Mega Markets and world cities.

What could have been Tel Aviv's regional status if the Oslo accord ended with full peace in our region? Would Tel Aviv 'going global' be a periphery, or rather evolve into vital hubs of the region's world cities? Candid calculations were made following Oslo accord in 1993. They resulted in two scenarios:

- The emerging new era of peace and tranquility would encourage foreign investors to up grade their investments in Israel.

- The creation of a 'New Mideast', wherein Israel and its neighbors would co-exist in peace, and would together strive to develop a regional market similar to Sassen's (2001) circuit model of inter-state cross-border transactions, investments, financial alliances, and labor markets. Major role in the success of this scenario, was allotted to the Palestinian Authority.

From start, it was clear that the two scenarios had different chances of realization. Whilst the first practically occurred, and largely contributed to Israel's economic boom of the 1990 s, the other had little chances to materialize. Besides the conceptual mismatch between 
the long time horizon needed to attain peace, and the short and diminishing time horizon needed for economic processes, Israel with close to $\$ 17,000$ GDP per capita in the late 1990s, is surrounded by poor Middle East economies with very low per capita GDP. In early 1990s the buying power of the relatively rich Persian Gulf countries of Israeli goods and services was estimated at $\$ 170$ million, equal to two thirds of what Israel exported to Switzerland. Similarly, the GDPs of 13 Middle East countries, excluding Iran and Iraq amounted to only $80 \%$ of the mid-1990s GDP of Canada, one of Israel's affluent markets. The estimated sales from Israel to all of its neighboring Arab countries if full peace prevailed would reach the $\$ 1$ billion mark by the year 2000 , an insignificant sum compared to Israel's total exports to the leading global markets. Also the projected economic impact of peace on economic relations of Israel and Palestinian Authority was gloomier still. In 1993 their GDP was only 5\% of Israel's. As a result the most promising joint ventures were narrowed to include law skilled labor flows, and swift migration of labor-intensive Industries from Israel to the West Bank and Gaza, and to Jordan too. Even in the year 2000 the situation seemed to be the same, as reported by Hershman (1999), who expressed reservations on the real potential of hi-tech, one of Israel's main assets, to become a Middle East elixir. Consequently, Tel Aviv's 'going global' could only be a regional 'cul-de-sac', exclusively affiliated with the mainstream of world cities.

\section{CONCLUDING REMARKS}

Tel Aviv referred to as a 'world city' in the early 1990s but its world city-ness attributes have taken off from the 1990s to the present. However, due to Middle East geopolitics it evolved as an alien entity to the region's 'wannabe world cities' network described by Stanley (2001). It represents a unique case of a peripheral dead-end world city, utterly affiliated with the major Mega Markets of the global economy, and to the mainstream of the world cities' network. In addition to the shaky peace-terror reality, the gap between Israel's economy and lifestyle and that of its bordering Arab states indicate that the above cul-desac reality would prevail for many years.

The roles played by Tel Aviv among the world's urban system established long before our times. They were rooted in Jaffa, the 'mother city' of Tel Aviv since the mid $19^{\text {th }}$ century, and later a part of it. From the 1920s Tel Aviv, that absorbed increasing numbers of Jewish immigrants who landed in Jaffa port, has started to develop its own economic base, to become the economic, social and cultural center of the rejuvenated Jewish community In the Land of Israel. It became the home of the Jewish elite, the agency actors for the development of Israel at large. All major financial and other economic institutions and corporations, political movements, daily and evening newspapers, publishing houses, music and theater groups, art associations, and many other 'institutions' that had formed the basis for Israel as an independent entity, began their life in Tel Aviv, and have remained there ever since. Yet, Tel Aviv, a '24-hour-city' and the hub of Greater Tel Aviv, emerged as a world city caliber only in late 1980s and early 1990s in association with the Israel's entry into the post-industrial age and its expanding links with the global economy. 
Tel Aviv is a vivid modern city with secular, cosmopolitan, and young ambience, and growing economy (Griver, 1999; Kummer, 2000). During the 1990s it enjoyed a continuous increase in world city attributes like advanced producer services, finance institutions, some with affiliates in other urban centers, and growing numbers of command and control head offices. Yet its advanced hi-tech, R\&D-intensive, industry, much of it set off by FDI and by the world's top hi-tech giants, have placed Tel Aviv at the core of the global economy (Kipnis, 2001). The above process was fuelled by swift real estate developments associated with its hi-tech and its associated producer and technical services. These developments led to the construction of a series of high-rise office and of high-status residential structures. Close to 60 of them built during the 1990s, and completely altered the City skyline.

In this paper most attention has been devoted to Tel Aviv's 'going global' by emphasizing, in the first place, economic and spatial attributes. However, the restructuring processes that have helped grant Tel Aviv 'world city' standing, also resulted in polarized social structure, dividing Tel Aviv between the well-off 'northerners' and the hard-up 'southerners'. Like in many other world cities, in Tel Aviv too, the well off are more visible and influential. Tikolsker (2000) article 'Tel Aviv: A City for Rich Families Only' showed that in 1998 some $23 \%$ of the dwelling units built in Tel Aviv had 6+ rooms compared to only $5 \%$ in 1990 , and $1-2$ room's units constituted $11 \%$, compared with only $1.6 \%$ in 1990 . It is a common phenomena that small central city dwellings are an ordinary type of residence for young skilled producer services and command outlets workers, in many cases DINKS (double income no kids) or SINKS (single income no kids). Finally, the 1990 per capita GDP of Tel Aviv district, the core of the metropolis was more than $50 \%$ higher than the country's. The projected 2020 GDP for Tel Aviv district is $45 \%$ above the national, despite the foremost goal of the 'Israel 2020' plan is to carry on the national population (and economy) dispersal policy (Mazor and Trop, 1994).

\section{References}

Arazi, D. 1998: “Three spokes in the wheel”. Israel's business arena - Globes, January 22.

Beaverstock, J.V., Smith, R. G., and Taylor, P. J. 1999: “A Roster of World Cities”. Cities, 16 (6), pp. 445-458. Also in the GWC study group site (GawC Inventory of World Cities) bulletin 5 .

Beaverstock, J.V., Smith, R. G., and Taylor, P. J. 2000: "World-city network: a new metageography?" Annals of the Association of American Geographers, 90, 1, pp.123-134.

Friedmann, J. 1986: "The world city hypothesis". Development and Change, Vol. 1, No. 1, pp. $69-84$.

Friedmann, J. 1995: "Where we stand: a decade of world city research". In Knox, P. L. and Taylor, P. J. (eds.), World cities in a world system. Cambridge: Cambridge University Press, pp. 21-47.

Gappert, G., 1989: "Global thinking and urban planning". In Knight, R. V. and

Gappert, G. (eds.), Cities in Global Society. Newbury Park: Sage, pp. 305-325. 
Geocities 2001: "High rise of London and Tel Aviv". www.geocities.com

Goldberg, M. A., and Davis, H. C. 1988: Global cities and public policy, the case of Vancouver British Columbia. Vancouver: School of Community Planning, University of British Columbia.

Griver, S. 1999: "Tel Aviv turns ninety”. Israel Magazine-on-The-Web, June issue. www.mfa.gov.

Hershman, T. 1999: "Hi-tech: the Mideast Elixir". Lycos Network www.wired.com. /news.

Kark, R. 1984: Jaffa - a city in evolution 1799 - 1917. Jerusalem: Yad Izhak Ben-Zvi Publications (Hebrew).

Kellerman, A. 1986: "Characteristics and trends in the Israeli service economy", The Service Industries Journal, 6, pp. 205 - 226.

Kellerman, A. 1993: Society and settlement: Jewish Land of Israel in the twentieth century. Albany: State University of New York Press.

Kipnis, B. A. 1997: "Dynamics and potentials of Israel's megalopolitan processes". Urban Studies, 34, 3, pp. 589-501.

Kipnis, B. A. 1998: "Spatial reach of office firms: case study in the Metropolitan CBD of Tel Aviv, Israel". Geografiska Annaler, 80 B, pp 17-28.

Kipnis, B. A. 2001: "Tel Aviv, Israel - a world city in evolution: urban development at a dead-end of global economy". GaWC Research Bulletin \#57, in GaWC site: www.lboro.ac.uk/gawc, 2001.

Kipnis, B. A. and Borenstein, O. 2001: "Patterns of Ssburban office development and spatial reach of their office firms: a case study in Metropolitan Tel Aviv, Israel". In Felsenstein, D., and Taylor, M. (Eds.), Promoting local growth: process, practice and policy. London: Ashgate, (in press).

Kipnis, B. A. and Noam, T. 1998: "Restructuring of a metropolitan suburban industrial park: case study in metropolitan Tel Aviv, Israel". Geografiska Annaler B, pp. 217-227.

Knight, R.V. and G. Gappert 1984: "Cities and the challenge of the global economy". In Bingham, R. D. and J. P. Blair (eds.), Urban economic development, urban affairs annual reviews, 27, Beverley Hills: Sage, pp. $63-78$.

Kummer, C. 1995: "Tel Aviv: the secular city where Israel meets the world". Travel, December issue. www.theatlantic.com

Lipshitz, G. 1996: "Core vs. periphery in Israel over time: inequality, internal migration, and immigration". In Gradus, Y. and Lipshitz, G. (eds.), The Mosaic of the Israeli Geography. Beer Sheva: Ben-Gurion University Press, pp. 13-28.

Mazor, A. and Trop, T. (eds.) 1994: Spatial alternatives for Israel in the $21^{\text {st }}$ century. Second Stage, Report No. 21. Haifa: The Technion (Hebrew).

Pasternak, E. 1993: Tel Aviv - industrial zones: an extension of land-use definitions. Tel Aviv: Tel Aviv Municipality (Hebrew).

Perman, S. 2000: "Startup nation". features, November issue. www. Business2.com

Ram, H. 1982: The Jewish Community of Jaffa from the second half of the 18th century to the first years of the British Mandatory Government. Ramat Gan: Bar Illan University. Ph.D. thesis (Hebrew). 
Sassen, S. 1991: The global city: New York, London Tokyo. Princeton: Princeton University Press.

Sassen, S. 2001: "Locating cities on global circuits". GWC Study Group Web Site (www. ibro.ac.uk) Bulletin 46 8.6.2001. (Forthcoming in Global Networks / Linked Cities).

Scott, A.J. 2000: Global city-regions. Oxford: Oxford University Press.

Small, J. and Witherick, M. 1986: A Modern dictionary of geography. London: Edward Arnold.

Stanley, B. 2001: "Going global" and wannabe world cities: conceptualizing regionalism in the Middle East". GWC Study Group Web Site (www.ibro.ac.uk) Bulletin 45 8.6.2001.

Stegman, M.A. and Turner, M.A. 1996: "The future of urban America in the global economy". Journal of the American Planning Association, 62 (2), pp. 157-164.

Storper, M. 1997: The regional world: territorial development in a global economy. New York: Guilford Press.

Tikolsker Y. 2000: "Tel Aviv: a city for rich families only". Haaretz, September 20, 2000 (Hebrew). 